\title{
Imaging Features of Susac Syndrome on High-Resolution Intracranial Vessel Wall MRI
}

Noushin Yahyavi-Firouz-Abadi, MD, Matthew Kiczek, DO, Steven R. Zeiler, MD, and Bruce A. Wasserman, MD

Neurol Neuroimmunol Neuroinflamm 2021;8:e994. doi:10.1212/NXI.0000000000000994
Correspondence

Dr. Yahyavi-Firouz-Abadi

nyahyavi@gmail.com.

An 18-year-old woman with a history of vertigo and longstanding fluctuating hearing loss presented with increasing headaches, nausea, dizziness, confusion, and gait imbalance. She also experienced new onset rashes on her hands and intermittent episodes of eye pain. CSF analysis revealed lymphocytic pleocytosis (14 lymphocytes), increased protein $(278 \mathrm{mg} / \mathrm{dL})$, and normal glucose (60 mg/dL). CSF viral PCR (HSV, CMV, VZV, EBV, West Nile, and Enterovirus), fungal, bacterial cultures, and serologic tests for variety of infections including Rickettsia, Bartonella, Mycoplasma, Leptospira, Erlichia, and Toxoplasma were negative. No evidence of immunodeficiency was identified. MRI of the brain demonstrated multiple scattered small foci of diffusion restriction (figure, A) with associated increased signal on T2-fluid-attenuated inversion recovery (FLAIR) sequences (figure, B) predominantly involving the deep and periventricular white matter with a predilection for the corpus callosum (figure, C). Lesions were also seen in the deep gray matter structures and brainstem. Most lesions enhanced. Ophthalmology evaluation revealed retinal atrophy. Fluorescein retinal angiogram showed foci of decreased perfusion, retinal branch occlusion with cotton wool spots, and retinal hemorrhages. Given the clinical suspicion of vasculitis, intracranial vessel wall imaging was performed. Postcontrast high-isotropic resolution vessel wall MRI (VWMRI) (figure, D-F) demonstrated foci of abnormal patchy parenchymal enhancement in the brainstem as well as deep gray nuclei and thalami (figure, E). Numerous linear foci of enhancement involving small vessels with perivascular involvement were seen radiating through the brain parenchyma suggesting vasculitis ${ }^{1}$ (figure, D). Bilateral abnormal enhancement of inner ear structures including the cochlea and semicircular canals was incidentally observed on VWMRI (figure, F).

\section{Discussion}

The triad of sensorineural hearing loss, acute encephalopathy, and retinal arteriolar branch occlusions along with imaging features of vascular/perivascular and cochleovestibular inflammation are consistent with the diagnosis of Susac syndrome. Susac syndrome or retinocochleocerebral vasculopathy is a rare microangiopathy that primarily affects women in their third decade. ${ }^{2}$ Previously described imaging features include the classic central callosal and pericallosal "snowball" lesions, microinfarcts, deep gray matter lesions, and leptomeningeal enhancement. ${ }^{2}$ This is the report of 2 additional imaging features of Susac syndrome: small vessel/perivascular enhancement and cochleovestibular enhancement.

Susac syndrome is a neuroinflammatory condition that can affect small vessels. Neuropathologic studies on Susac syndrome are limited. Reported findings that may explain small vessel or perivascular enhancement include perivascular inflammation with the presence of mononuclear cells around the arterioles, arteriolar wall thickening, ${ }^{3}$ basement membrane thickening, collagen deposition in the perivascular space, and microvascular fibrosis. ${ }^{4}$

In addition to the classic brain imaging features of Susac, clinical findings are pivotal to this rare diagnosis. The patient had an extensive workup for infectious etiologies, immunodeficiency,

From the Division of Neuoradiology (N.Y.-F.-A., B.A.W.), The Russell H. Morgan Department of Radiology and Radiological Sciences, Johns Hopkins University, Baltimore, MD; Department of Radiology (M.K.), Clevelend Clinic Foundation, Cleveland, OH; and Department of Neurology (S.R.Z.), Johns Hopkins University, Baltimore, MD. 

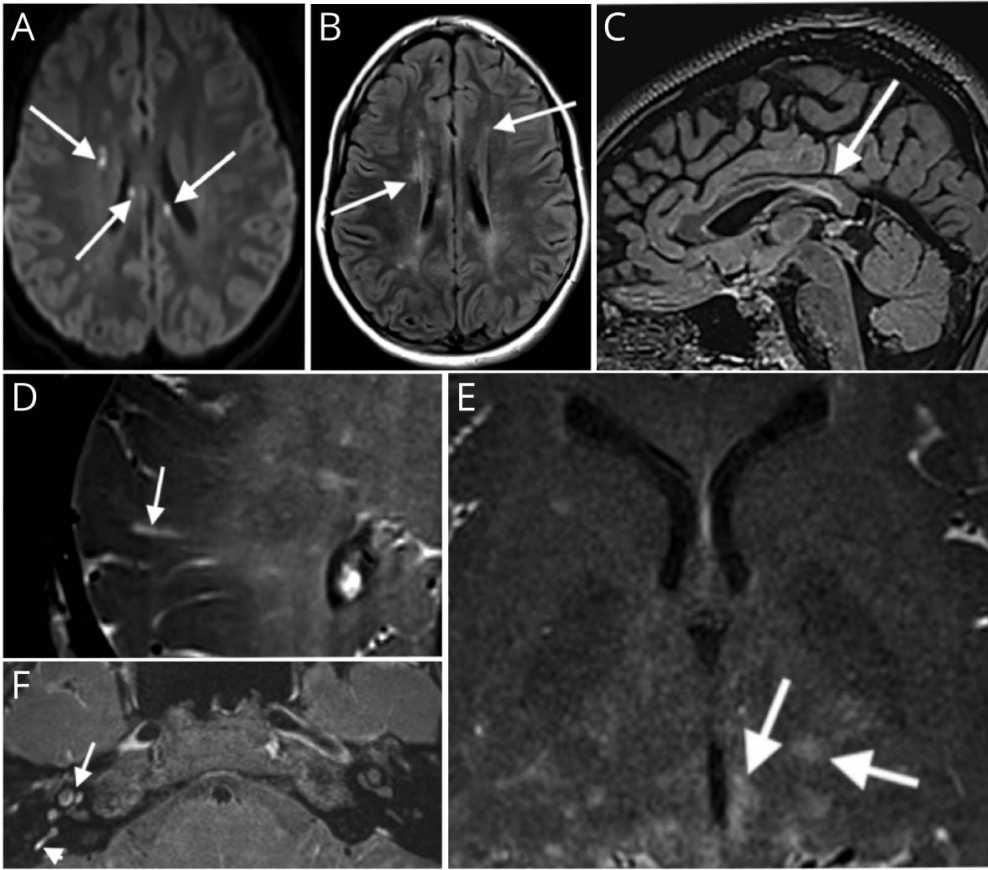

(A) Axial diffusion-weighted acquisition demonstrates foci of microinfarcts involving the corpus callosum and periventricular white matter (arrows). There is associated edema on axial T2-FLAIR acquisition ( $B$, arrows) with the involvement of central fibers of corpus callosum seen on sagittal T2-FLAIR sequence $(C$, arrow). Postcontrast high-isotropic resolution (acquired resolution, $0.52 \times 0.52 \times 0.52 \mathrm{~mm}^{3}$ ) $3 \mathrm{D}$ vessel wall MRI shows an enhancing parenchymal vessel with mild perivascular enhancement compatible with small vessel vasculitis (D, arrow). Multiple foci of patchy enhancement are seen involving the brainstem and deep gray matter ( $E$, arrows). Enhancement of the right cochlea ( $\mathrm{F}$, long arrow) and semicircular canals ( $F$, short arrow) is demonstrated. and other forms of vasculitis, which was negative. The presence of hearing loss with abnormal enhancement of inner ear structures on high-resolution MRI points to the inflammatory changes in the cochlea and semicircular canals. The patient experienced fluctuating bouts of hearing loss and vertigo since age 7 which were partially responsive to steroid treatment but overall progressed. Furthermore, fluorescein angiography of the retina demonstrates areas of hypoperfusion because of branch retinal artery occlusion. This constellation of imaging findings and clinical features makes Susac syndrome the most likely diagnosis. The patient improved after treatment with immunosuppressants, including corticosteroids, as well as IV immunoglobulin. Further studies are warranted to evaluate imaging features of Susac on VWMRI compared with other forms of CNS vasculitis and the role of VWMRI for characterizing vasculitis activity and efficacy of its treatment.

\section{Study Funding}

The authors report no targeted funding.

\section{Disclosure}

The authors report no disclosures relevant to the article. Go to Neurology.org/NN for full disclosures.

\section{Publication History}

Received by Neurology: Neuroimmunology \& Neuroinflammation January 12, 2021. Accepted in final form February 15, 2021.
Appendix Authors

\begin{tabular}{|c|c|c|}
\hline Name & Location & Contribution \\
\hline $\begin{array}{l}\text { Noushin } \\
\text { Yahyavi- } \\
\text { Firouz- } \\
\text { Abadi, MD }\end{array}$ & $\begin{array}{l}\text { Division of Neuoradiology, } \\
\text { The Russell H. Morgan } \\
\text { Department of Radiology } \\
\text { and Radiological Sciences, } \\
\text { Johns Hopkins University, } \\
\text { Baltimore, MD }\end{array}$ & $\begin{array}{l}\text { Drafting/revision of the } \\
\text { article for content, } \\
\text { including medical writing } \\
\text { for content; major role in } \\
\text { the acquisition of data; } \\
\text { study concept or design }\end{array}$ \\
\hline $\begin{array}{l}\text { Matthew } \\
\text { Kiczek, DO }\end{array}$ & $\begin{array}{l}\text { Department of Radiology, } \\
\text { Clevelend Clinic } \\
\text { Foundation, Cleveland, } \mathrm{OH}\end{array}$ & $\begin{array}{l}\text { Drafting/revision of the } \\
\text { article for content, including } \\
\text { medical writing for content }\end{array}$ \\
\hline $\begin{array}{l}\text { Steven R. } \\
\text { Zeiler, MD }\end{array}$ & $\begin{array}{l}\text { Department of Neurology, } \\
\text { Johns Hopkins University, } \\
\text { Baltimore, MD }\end{array}$ & $\begin{array}{l}\text { Drafting/revision of the } \\
\text { article for content, including } \\
\text { medical writing for content }\end{array}$ \\
\hline $\begin{array}{l}\text { Bruce A. } \\
\text { Wasserman, } \\
\text { MD }\end{array}$ & $\begin{array}{l}\text { Division of Neuoradiology, } \\
\text { The Russell H. Morgan } \\
\text { Department of Radiology } \\
\text { and Radiological Sciences, } \\
\text { Johns Hopkins University, } \\
\text { Baltimore, MD }\end{array}$ & $\begin{array}{l}\text { Drafting/revision of the } \\
\text { article for content, } \\
\text { including medical writing } \\
\text { for content; major role in } \\
\text { the acquisition of data; } \\
\text { study concept or design }\end{array}$ \\
\hline
\end{tabular}

\section{References}

1. Zeiler S, Qiao Y, Pardo C, Lim M, Wasserman BA. Vessel wall MRI for targeting biopsies of intracranial vasculitis. Am J Neuroradiol. 2018;39:2034-2036.

2. Dorr J, Krautwald S, Wildemann B, et al. Characteristics of Susac syndrome: a review of all reported cases. Nat Rev Neurol. 2013;9:307-316.

3. Agamonolis DP, Klonk C, Bigley K, et al. Neuropathological findings in Susac Syndrome: an autopsy report. J Neuropathol Exp Neurol. 2019;78:515-519.

4. Agamanolis DP, Prayson RA, Asdaghi N, et al. Brain microvascular pathology in Susac syndrome: an electron microscopic study of five cases. Ultrastructural Pathol. 2019;43: 229-236. 


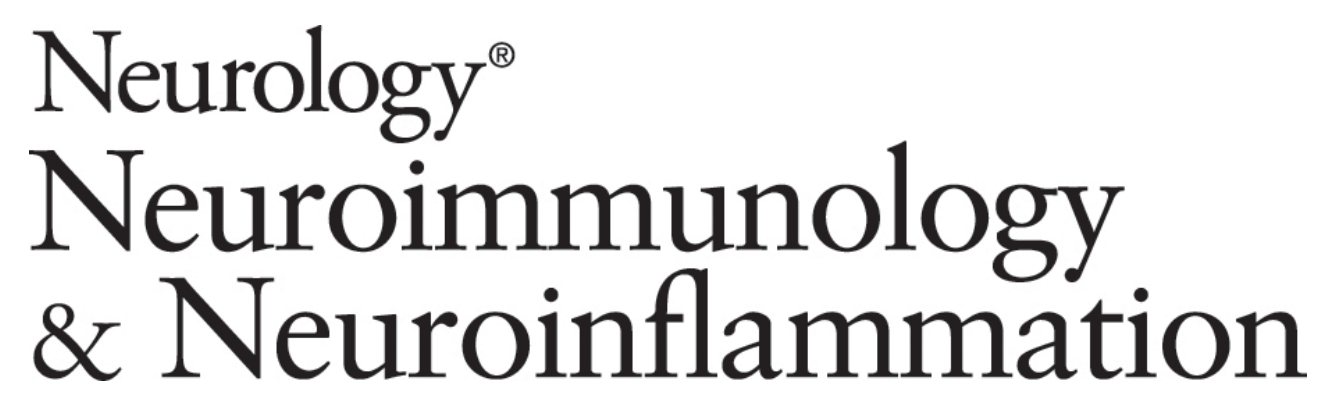

Imaging Features of Susac Syndrome on High-Resolution Intracranial Vessel Wall

Noushin Yahyavi-Firouz-Abadi, Matthew Kiczek, Steven R. Zeiler, et al.

Neurol Neuroimmunol Neuroinflamm 2021;8;

DOI 10.1212/NXI.0000000000000994

This information is current as of April 16, 2021

Neurol Neuroimmunol Neuroinflamm is an official journal of the American Academy of Neurology.

Published since April 2014, it is an open-access, online-only, continuous publication journal. Copyright

Copyright $\odot 2021$ The Author(s). Published by Wolters Kluwer Health, Inc. on behalf of the American

Academy of Neurology.. All rights reserved. Online ISSN: 2332-7812.

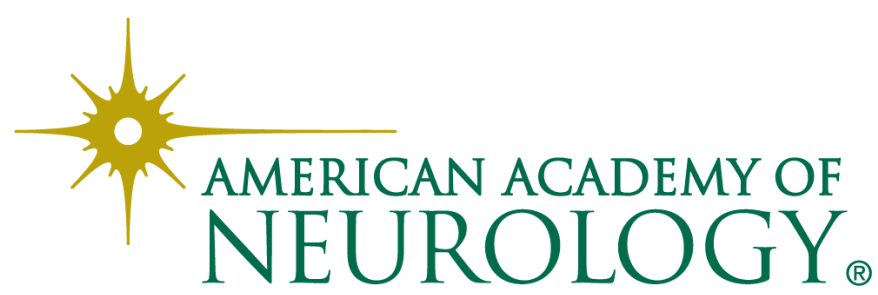




\section{Updated Information \& Services}

References

Citations

Subspecialty Collections

Permissions \& Licensing

Reprints including high resolution figures, can be found at:

http://nn.neurology.org/content/8/4/e994.full.html

This article cites 4 articles, 1 of which you can access for free at: http://nn.neurology.org/content/8/4/e994.full.html\#\#ref-list-1

This article has been cited by 2 HighWire-hosted articles: http://nn.neurology.org/content/8/4/e994.full.html\#\#otherarticles

This article, along with others on similar topics, appears in the following collection(s):

All Demyelinating disease (CNS)

http://nn.neurology.org//cgi/collection/all_demyelinating_disease_cns MRI

http://nn.neurology.org//cgi/collection/mri

Stroke in young adults

http://nn.neurology.org//cgi/collection/stroke_in_young_adults

Vasculitis

http://nn.neurology.org//cgi/collection/vasculitis

Information about reproducing this article in parts (figures,tables) or in its entirety can be found online at:

http://nn.neurology.org/misc/about.xhtml\#permissions

Information about ordering reprints can be found online:

http://nn.neurology.org/misc/addir.xhtml\#reprintsus

Neurol Neuroimmunol Neuroinflamm is an official journal of the American Academy of Neurology.

Published since April 2014, it is an open-access, online-only, continuous publication journal. Copyright

Copyright $\odot 2021$ The Author(s). Published by Wolters Kluwer Health, Inc. on behalf of the American

Academy of Neurology.. All rights reserved. Online ISSN: 2332-7812.

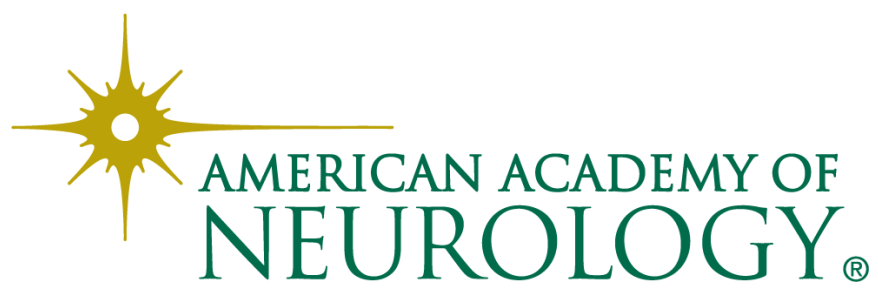

